\title{
ANALISIS ASESMEN DALAM PEMBELAJARAN MATA KULIAH BUNPOU V (TATA BAHASA V) DENGAN MENGGUNAKAN METODE PROBLEM BASED LEARNING DI JURUSAN PENDIDIKAN BAHASA JEPANG UNIVERSITAS PENDIDIKAN GANESHA TAHUN AJARAN 2015/2016
}

\author{
M. D. A. Indah Pratiwi ${ }^{1}$, D. M. S. Mardani ${ }^{2}$, I. W. Sadyana ${ }^{3}$ \\ Jurusan Pendidikan Bahasa Jepang, \\ Universitas Pendidikan Ganesha \\ Singaraja, Indonesia \\ e-mail: adelina.indah31@yahoo.com \\ desak.mardani@undiksha.ac.id wayan.sadyana@undiksha.ac.id
}

\begin{abstract}
Abstrak
Penelitian ini bertujuan untuk 1) mendeskripsikan penilaian proses pada mata kuliah Bunpou $\mathrm{V}$ dengan penerapan metode Problem Based Learning. 2) mendeskripsikan penilaian akhir pada mata kuliah Bunpou $\mathrm{V}$ dengan penerapan metode Problem Based Learning. Penelitian ini merupakan penelitian kualitatif. Subjek penelitian ini adalah dosen pengampu mata kuliah Bunpou $V$ dan mahasiswa kelas A dan B yang mengikuti pembelajaran mata kuliah Bunpou V. Metode pengumpulan data menggunakan wawancara, observasi dan dokumentasi. Teknik analisis data dalam penelitian ini adalah deskriptif analisis kualitatif. Hasil penelitian menunjukkan bahwa, 1) Penilaian proses diperoleh dari aktivitas mahasiswa selama perkuliahan berlangsung yakni berupa penilaian terhadap hasil presentasi, hasil diskusi, dan penilaian untuk keaktifan secara individu. 2) Penilaian akhir dilaksanakan dengan memberikan tes tulis yang diberikan pada saat UTS dan UAS untuk mengetahui kemampuan mahasiswa serta memperoleh nilai akhir pada proses pembelajaran.
\end{abstract}

Kata kunci : Penilaian, Problem Based Learning, Bunpou

要旨

本研究の目的は、（1）日本語教育学科「文法V」科目におけるプログラム ベースラーニングに基づくプロセス評価、（2）「文法 $\mathrm{V} 」$ 科目におけるプログラム ベースラーニングに基づく最終評価を明らかにすることである。この研究は、定性的調查を利用した 調査協力者は、日本語教育学科の「文法 $\mathrm{V} 」$ 科目で指導する教師及びAとB教室の学習者である。調 查データは、観察、インタビューより収集し、それを定性的記述法により分析した。分析の結果、 1）プロセス評価は発表・ディスカッション・個人の活力というような活動が評価された。

学習者能力を図り、学習の最終評価を得られるように、最終評価は、中間試験及び期末試験という筆 記試験を通して行われた。

キーワード : 評価、プログラムベースラーニング、文法

\section{Pendahuluan}

Problem Based Learning adalah suatu metode pembelajaran dalam bentuk kelompok kecil berbasis masalah dimana sekelompok pebelajar dan fasilitator berdasarkan masalah berkolaborasi untuk mengidentifikasi tujuan dan kebutuhan belajar yang diikuti dengan belajar mandiri, menerima masukan dan menarik kesimpulan berdasarkan kesepakatan kelompok (Khadafianto et al., 2016). Dengan penerapan metode pembelajaran Problem Based Learning, mahasiswa dapat saling bertukar pendapat mengenai kesulitan dalam memecahkan masalah yang diberikan dosen terkait mata kuliah Bunpou V.Penilaian pada metode Problem Based Learning terdiri dari penilaian proses dan penilaian produk. Penilaian proses berupa aktivitas mahasiswa selama pembelajaran, sedangkan penilaian produk dapat berupa penilaian terhadap hasil tes tertulis.

Keberhasilan penerapan metode pembelajaran Problem Based Learning dalam mata kuliah Bunpou V didukung oleh penelitian serupa yang dilakukan oleh Mardani dan Adnyani 
(2015), salah satu dosen pengampu mata kuliah Bunpou (Tata Bahasa) di Jurusan Pendidikan Bahasa Jepang, Universitas Pendidikan Ganesha. Penelitian yang dilakukan berjudul "Implementasi Metode Problem Based Learning pada mata kuliah Bunpou IV di Jurusan Pendidikan Bahasa Jepang Universitas Pendidikan Ganesha". Pada penelitiannya dijelaskan bahwa metode pembelajaran tata bahasa Jepang (Bunpou) saat ini masih memusatkan perhatian pada pengajar (teacher center) melalui hasil pre-test diketahui kemampuan mahasiswa mengenai penguasaan tata bahasa Jepang sangat rendah sehingga perlu dilakukan pembenahan metode pembelajaran. Hasil penelitian ini menunjukkan penerapan metode Problem Based Learning memberikan efek yang positif terhadap kemampuan tata bahasa Jepang bagi pebelajar. Tujuan dilakukan penelitian ini adalah untuk mengetahui strategi yang dilakukan, mengetahui aktivitas selama pembelajaran, dan untuk mengetahui respon terhadap penggunaan metode pembelajaran pada perkuliahan Bunpou IV (Tata Bahasa IV).

Namun pada penilaian metode Problem Based Learning belum dilakukan penelitian, sehingga peneliti tertarik melakukan penelitian pada aspek penilaian dengan metode pembelajaran Problem Based Learning. Penilaian yang akan dibahas yaitu mengenai penilaian proses dan akhir.

Dalam pelaksanaannya mata kuliah Bunpou $\mathrm{V}$ memiliki beberapa kendala yang diketahui berdasarkan wawancara dengan beberapa mahasiswa semester V. Berdasarkan hasil wawancara tersebut, mahasiswa semester $\mathrm{V}$ masih memiliki kebingungan dalam menentukan partikel yang tepat untuk membuat pola kalimat yang benar. Oleh karena itu, diperlukan adanya suatu inovasi pembelajaran yang dapat memudahkan pemahaman mahasiswa terhadap materi pada mata kuliah Bunpou V. Salah satu metode pembelajaran yang tepat adalah metode pembelajaran Problem Based Learning.

Berdasarkan latar belakang tersebut, maka penting untuk dilakukan penelitian dengan judul "Analisis Asesmen dalam Pembelajaran Mata Kuliah Bunpou V (Tata Bahasa V) dengan Menggunakan Metode Problem Based Learning di Jurusan Pendidikan Bahasa Jepang Universitas Pendidikan Ganesha Tahun Ajaran 2015/2016" Penelitian yang diadakan ini memiliki tujuan untuk menjawab beberapa permasalahan yang telah dikemukakan dalam rumusan masalah sebagai berikut: 1) Untuk mendeskripsikan penilaian proses pada mata kuliah Bunpou V (Tata Bahasa V) dengan penerapan metode Problem Based Learning pada mahasiswa semester enam Jurusan Pendidikan Bahasa Jepang tahun ajaran 2015/2016. 2) Untuk mendeskripsikan penilaian akhir pada mata kuliah Bunpou V (Tata Bahasa V) dengan penerapan metode Problem Based Learning pada mahasiswa semester enam Jurusan Pendidikan Bahasa Jepang tahun ajaran 2015/2016.

Untuk dasar teori yang digunakan untuk menganalisis data penelitian ini menggunakan teori asesmen pembelajaran yang meliputi tujuan, prinsip, teknik asesmen. Adapun juga untuk teori mengenai jenis-jenis tes yang meliputi model tes objektif. Selain itu, mengenai teori metode pembelajaran Problem Based Learning.

\section{Metode}

Dalam penelitian ini pendekatan yang dilakukan adalah melalui pendekatan kualitatif. Yang dimaksud penelitian kualitatif itu tidak berupa angka tetapi data tersebut berasal dari catatan lapangan, dokumen, dan memo. Penelitian kualitatif adalah metode yang digunakan untuk meneliti kondisi yang alamiah dan peneliti sebagai instrumen utama. Sedangkan untuk jenis penelitian yang digunakan adalah penelitian deskriptif. Penelitian deskripstif adalah suatu metode penelitian yang ditujukan untuk menggambarkan fenomena-fenomena yang ada, yang berlangsung saat ini atau saat yang lampau. Penelitian ini tidak mengadakan manipulasi atau pengubahan pada variabel-variabel bebas, tetapi menggambarkan suatu kondisi apa adanya. Penggambaran kondisi bisa individual atau menggunakan angka-angka (Sukmadinata, 2006).

Lokasi penelitian merupakan tempat yang dijadikan pusat untuk melaksanakan penelitian. Adapun lokasi penelitian yang dipilih adalah ruang kelas Jurusan Pendidikan Bahasa Jepang dimana dilaksanakannya kuliah Bunpou V (Tata Bahasa V). 
Sumber data primer, yaitu data yang langsung dikumpulkan oleh peneliti (atau petugasnya) dari sumber pertamanya (Suryabrata, 1987). Adapun yang menjadi sumber data primer dalam penelitian ini berupa catatan hasil wawancara yang diperoleh melalui wawancara dengan dosen pengampu mata kuliah Bunpou V (Tata Bahasa V). Selain itu observasi dilakukan pada mahasiswa dan dosen mengenai penilaian pembelajaran dengan menggunakan metode Problem Based Learning. Sumber data sekunder, yaitu data yang langsung dikumpulkan oleh peneliti sebagai penunjang dari sumber pertama atau data yang tersusun dalam bentuk dokumen-dokumen (Suryabrata, 1987). Adapun yang menjadi sumber data sekunder dalam penelitian ini diambil dari studi dokumentasi berupa soal-soal shoutesuto, UTS, dan UAS serta hasil tes tersebut. Selain itu, dokumen yang dikumpulkan berupa deskripsi mata kuliah, silabus mata kuliah, kontrak perkuliahan.

Suatu penelitian yang baik seharusnya memiliki subjek yang akan dijadikan sebagai pendukung peneliti dalam melaksanakan suatu penelitian. Arikunto (2006) menyatakan subjek penelitian adalah benda, hal, atau anggota kelompok tempat yang dibahas dalam penelitian. Subjek penelitian adalah setiap pendukung atau anggota kelompok yang dapat memberikan informasi mengenai masalah yang diangkat dan dibahas oleh peneliti dalam sebuah penelitian. Dalam penelitian ini yang menjadi subjek penelitian adalah dosen pengampu mata kuliah Bunpou $\mathrm{V}$ dan mahasiswa tingkat III Jurusan Pendidikan Bahasa Jepang. Sedangkan objek dalam penelitian ini adalah bagian tahap asesmen pembelajaran terhadap penggunaan metode Problem Based Learning pada perkuliahan Bunpou V (Tata Bahasa V).

Untuk teknik pengumpulan data yang digunakan dalam penelitian ini menggunakan teknik pengumpulan data kualitatif, yaitu dengan metode observasi, wawancara dan metode dokumentasi.

Metode observasi merupakan alat pengumpul data yang banyak digunakan untuk mengukur tingkah laku atau proses terjadinya suatu kegiatan yang diamati (Sugiyono, 2009). Dan dalam penelitian ini, metode observasi diartikan sebagai pengamatan dan pencatatan secara sistematik terhadap gejala yang tampak pada objek penelitian. Observasi yang dilakukan dalam penelitian ini yaitu observasi terhadap proses asesmen yang dilakukan oleh dosen pengampu mata kuliah Bunpou $\mathrm{V}$ (Tata Bahasa V) dengan menggunakan metode pembelajaran Problem Based Learning. Observasi ini bertujuan untuk mengetahui teknik penilaian yang digunakan oleh dosen pengampu untuk memperoleh hasil akhir dari kemampuan mahasiswa yang mengikuti mata kuliah Bunpou V (Tata Bahasa V).

Menurut Moleong (2011:186) menyatakan bahwa metode wawancara adalah percakapan dengan maksud tertentu yang dilakukan oleh dua pihak yaitu pewawancara yang mengajukan pertanyaan dan terwawancara yang memberikan jawaban atas pertanyaan tersebut. Narasumber yang akan diwawancarai dalam penelitian ini adalah dosen pengampu mata kuliah Bunpou V. Dalam hal ini tujuannya untuk mengetahui informasi secara lebih mendalam dan terarah terkait dengan proses penilaian selama pembelajaran Bunpou $\mathrm{V}$ dengan menggunakan pedoman wawancara yang telah disiapkan yang selanjutnya informasi tersebut dicatat secara sistematis

Metode dokumentasi adalah mencari data mengenai hal-hal atau variabel yang berupa catatan, transkip, buku, surat kabar, majalah, agenda, dan sebagainya (Arikunto, 2006). Dalam penelitian ini, peneliti megumpulkan data seperti soal-soal shoutesuto, UTS, dan UAS serta hasil tes tersebut. Selain itu, dokumen yang dikumpulkan berupa deskripsi mata kuliah, silabus mata kuliah, kontrak perkuliahan.

Instrumen dalam penelitian ini berupa pedoman wawancara. Pedoman wawancara digunakan untuk mewawancarai dosen pengampu mata kuliah Bunpou V (Tata Bahasa V). Selain wawancara instrumen dalam penelitian ini berupa rubrik penilaian untuk penilaian proses dan tes tertulis untuk penilaian akhir. Rubrik penilaian proses dapat dilihat pada lampiran. Sedangkan tes tertulis berbentuk esai dan pilihan ganda yang diberikan ketika UTS dan UAS. Tes pada UTS berjumlah 39 butir soal pilihan ganda dengan skor masingmasing butir soal yaitu $0-1$, sedangkan tes pada UAS berjumlah 43 butir soal untuk pilihan ganda dengan skor masing-masing 0-1 dan 5 butir soal untuk esai dengan skor masingmasing butir soal 0-2. 
Teknik analisis data dalam penelitian ini adalah analisis kualitatif dengan tahapan: pengumpulan data, reduksi data, penyajian data, dan penarikan kesimpulan atau verifikasi.

\section{Hasil dan Pembahasan}

Hasil

Data Hasil Wawancara

Wawancara dalam penelitian ini dilakukan dengan dosen pengampu mata kuliah Bunpou V. Wawancara dilakukan pada tanggal 20 November 2017 di ruang Jurusan Pendidikan Bahasa Jepang. Wawancara dilakukan dengan menggunakan pedoman wawancara yang sudah disiapkan terkait dengan tahap asesmen atau penilaian. Tujuannya untuk mendapat informasi secara mendalam yang digunakan untuk memperkuat argumen dalam penelitian ini.

Berdasarkan hasil wawancara yang dilakukan dengan dosen pengampu mata kuliah Bunpou V pada tanggal 20 November 2017, dijelaskan bahwa jenis penilaian yang digunakan dalam mata kuliah Bunpou $\mathrm{V}$ dengan menerapkan metode Problem Based Learning yaitu penilaian proses dan penilaian akhir. Penilaian proses diperoleh dari hasil diskusi kelompok dan presentasi kelompok selama proses pembelajaran. Pada diskusi kelompok diamati dan dinilai kemampuan menyelesaikan masalah yang diberikan secara berkelompok, dimana dosen pengampu telah memberikan materi pembelajaran berupa task sebelum perkuliahan berlangsung untuk bahan diskusi dalam proses pembelajaran. Task tersebut menguji kemampuan menemukan perubahan kosakata yang terjadi ketika digabungkan dengan suatu pola tertentu. Sedangkan pada presentasi kelompok dinilai seberapa baik penyampaian presentasi tersebut, serta ketepatan analisis pada task yang diberikan. Ada 2 aspek yang dinilai dalam penilaian proses yaitu kemampuan mengidentifikasikan konsep dan mengaplikasikan konsep dalam memecahkan masalah. Point tersebut dikumpulkan secara keseluruhan dari awal sampai akhir perkuliahan yang nantinya akan menjadi nilai untuk proses selama pembelajaran.

Poin nilai dari presentasi kelompok ini akan diakumulasikan pada aspek tugas yang mencakup keaktifan, diskusi, dan presentasi kelompok mahasiswa yang diberi bobot sebesar $30 \%$. Ketika ada satu hal atau ada permasalahan yang tidak terjawab dari hasil presentasi, dosen pengampu akan melempar pertanyaan kepada kelompok lain. Jika salah satu anggota kelompok lain ada yang bisa menjawab, maka poin tersebut akan dimasukkan ke penilaian individual. Dalam hal ini terdapat penilaian individu pada saat proses pembelajaran.

Pada penilaian proses memiliki beberapa kendala dalam pelaksanaannya yaitu dosen pengampu mata kuliah Bunpou $\mathrm{V}$ tidak sepenuhnya dapat memperhatikan seluruh mahasiswa setiap saat selama proses pembelajaran. Selain itu metode Problem Based Learning dalam penilaian prosesnya tidak dibuatkan rubrik penilaian, namun hanya sebatas pemberian poin. Untuk mengatasi masalah tersebut, alternatif pemecahan yang bisa dilakukan yaitu memberikan tanda untuk mahasiswa yang aktif selama proses pembelajaran berlangsung. Untuk kelanjutan penilaian proses pada metode Problem Based Learning, sebaiknya dicantumkan rubrik penilaiannya.

Setelah penilaian proses, maka penilaian akhir dilakukan. Penilaian akhir diperoleh dari hasil akhir tes yang sudah diberikan pada saat UTS dan UAS. Masing-masing butir soal pada tes tersebut diberikan skor. Dosen pengampu mata kuliah Bunpou V akan memberikan skor 1 pada tiap butir soal pilihan ganda, sedangkan skor 2 akan diberikan pada masingmasing butir soal esai. Maksud dari perbedaan pemberian skor ini yaitu untuk menjawab soal pilihan ganda dengan memilih pilihan jawaban yang sudah ada, akan lebih mudah dibandingkan dengan menjawab soal esai yang diperintahkan untuk membuat kalimat.

Terkait dengan metode Problem Based Learning tidak ada ketentuan khusus dalam pemberian pembobotan nilai secara keseluruhan. Pembobotan terkait dengan penilaian proses dan penilaian akhir sudah tertera pada kontrak kelas perkuliahan. Dalam satu semester perkuliahan ada 16 kali pertemuan termasuk UTS dan UAS. Ada dua aspek asesmen secara keseluruhan, yaitu asesmen proses (presentasi, shoutesuto, keaktifan) 
dengan bobot keseluruhan $30 \%$ dan asesmen produk (UAS dan UTS) dengan bobot keseluruhan $70 \%$.

Penilaian proses terdapat metode asesmen yaitu presentasi, Shoutesuto (tes kecil), dan keaktifan dengan bobot $30 \%$. Untuk nilai presentasi dirata-ratakan selama 14 kali pertemuan, begitu juga dengan nilai shoutesuto. Hasil rata-rata nilai presentasi dijumlahkan dengan hasil rata-rata nilai shoutesuto kemudian dibagi 2, lalu dijumlahkan dengan nilai keaktifan. Nilai keaktifan diperoleh dari pertanyaan yang diajukan ataupun pendapat yang diungkapkan. Setiap pertanyaan yang diajukan ataupun pendapat yang dikemukakan memperoleh nilai 1 poin. Poin tersebut dijumlahkan selama 14 kali pertemuan. Jumlah poin tersebut akan ditambahkan dengan rata-rata nilai presentasi dan shoutesuto yang telah digabungkan. Hasil keseluruhan dikalikan dengan bobot 30\%. Hasil tersebut akan menjadi nilai tugas mahasiswa selama 14 kali pertemuan.

Untuk nilai UTS dikalikan dengan bobot 30\%. Sedangkan nilai UAS dikalikan dengan bobot $40 \%$. Nilai tugas, UTS, dan UAS yang telah diperoleh dijumlahkan seluruhnya dan menjadi nilai akhir yang diperoleh mahasiswa.

\section{Data Hasil Observasi}

Berdasarkan hasil observasi secara langsung yang dilakukan selama proses pembelajaran, penilaian yang dilakukan oleh dosen pengampu mata kuliah Bunpou $\mathrm{V}$ (Tata Bahasa V) diawali dengan pemberian shoutesuto. Pemberian shoutesuto berguna untuk mengukur kemampuan awal yang dimiliki peserta didik mengenai materi yang akan diperlajari. Setelah pemberian shoutesuto proses penilaian dilanjutkan dengan menilai keaktifan mahasiswa pada saat diskusi kelompok dan presentasi. Ketika presentasi, dosen menunjuk secara acak anggota kelompok untuk mempresentasikan hasil diskusi kelompok. Dosen menilai seberapa baik penyampaian presentasi dari perwakilan kelompok. Presentasi ini terkait dengan seberapa mampu mahasiswa memecahkan masalah yang diberikan sesuai dengan metode Problem Based Learning. Hasil presentasi tersebut akan dimasukkan dalam penilaian kelompok. Setelah presentasi dari perwakilan kelompok, dilanjutkan dengan penilaian keaktifan mahasiswa secara individu dengan melihat mahasiswa yang aktif mengajukan pendapat ataupun menjawab pertanyaan. Dosen pengampu akan memberikan tanda centang $(\square)$ pada nama mahasiswa yang mengajukan pendapat ataupun menjawab pertanyaan. Tanda centang ( $\square$ ) tersebut dicantumkan pada daftar peserta kuliah yang dibawa oleh dosen pengampu. Penilaian inilah yang nantinya akan menjadi nilai penunjang individu mahasiswa. Pada akhir pembelajaran, dosen pengampu akan memberikan klarifikasi apabila ada permasalahan yang belum dipecahkan oleh mahasiswa.

Penilaian akhir dilakukan oleh dosen pengampu dengan memberikan soal UTS dan UAS. UTS diberikan kepada mahasiswa pada pertemuan ke-10, sedangkan UAS diberikan pada pertemuan ke-16. Hasil penilaian proses dan penilaianakhir akan diakumulasikan sesuai dengan bobot masing-masing.

\section{Data Hasil Dokumentasi}

Berdasarkan hasil dokumentasi, penilaian akhir pada mata kuliah Bunpou V menggunakan tes tulis. Butir soal diambil dari beberapa sumber buku lama yang ada kaitannya dengan materi pada mata kuliah Bunpou V ( Tata Bahasa V).

Pada kontrak kelas mata kuliah Bunpou V dijelaskan adanya tiga aspek penilaian, yaitu UTS (Ujian Tengah Semester) dengan bobot 30\%, UAS (Ujian Akhir Semester) dengan bobot $40 \%$, dan nilai tugas dengan bobot $30 \%$. Dari ketiga aspek tersebut, UTS dan UAS merupakan tes tulis, sedangkan nilai tugas merupakan akumulasi dari nilai hasil presentasi kelompok dengan nilai pembuatan kalimat oleh masing-masing individu. Tetapi terdapat salah satu aspek penilaian yang tidak dicantumkan dalam kontrak kuliah. Yaitu shoutesuto, merupakan tes kecil yang diberikan kepada mahasiswa guna mengukur sudah sejauh mana kemampuan mahasiswa memahami materi yang telah dibahas. Nilai dari shoutesuto kemudian diakumulasikan dengan nilai tugas.

Bertolak dari kontrak kuliah yang berlaku pada kelas mata kuliah Bunpou V, maka proses pengumpulan data difokuskan pada pengumpulan dokumentasi tes yang diberikan 
saat UTS, UAS, dan shoutesuto. Jumlah tes yang diberikan pada saat Ujian Akhir Semester (UAS) lebih banyak dibandingkan soal pada saat Ujian Tengah Semester (UTS), sedangkan soal pada shoutesuto hanya berjumlah 10 karena waktu pengerjaannya sangat singkat, sekitar 6 sampai 7 menit di awal perkuliahan.

Jumlah soal yang diberikan pada tes objektif lebih banyak dan waktu pengerjaannya lebih singkat dibandingkan bentuk tes esai. Pilihan jawaban objektif yang diberikan hanya mencocokkan dan memasukkan beberapa partikel pada sebuah kalimat yang rumpang.

Dalam pembuatan tes, sebelumnya dosen pengampu memberikan materi ajar yaitu berupa task atau tugas kepada mahasiswa untuk dikerjakan di rumah dan dipelajari sebelum perkuliahan dimulai. Task diberikan seminggu sebelum perkuliahan dimulai dengan tujuan agar mahasiswa dapat memberikan banyak latihan sebelumnya. Setelah semua task selesai dibahas, dosen memberikan sebuah tes kecil atau shoutesuto. Shoutesuto atau tes kecil ini diberikan pada awal sebelum perkuliahan dimulai. Tes kecil ini diberikan untuk mengukur kemampuan sudah sejauh mana kemampuan mahasiswa sudah memahami terhadap materi yang sudah dibahas. Kumpulan dari tes kecil atau shoutesuto yang sudah pernah diberikan, beberapa soal akan dimunculkan juga pada soal UTS dan UAS. Salah satu contoh task yang diberikan pada proses perkuliahan Bunpou V (Tata Bahasa V).

Dalam hal ini jika dikaitkan dengan penggunaan metode Problem Based Learning dalam pembuatan tes, sebelumnya akan diberikan task atau materi untuk dibahas. Pemberian materi tersebut akan muncul di soal-soal pada tes. Bertolak dari karakteristik metode Problem Based Learning, ketika diberikan task peserta didik juga dituntut untuk mampu berpikir untuk memecahkan masalah, menemukan jawaban yang ada dalam task tersebut dan mampu menganalisis dan mendemontrasikannya. Untuk model soal yang diberikan ketika tes berlangsung dosen pengajar memberikan model soal yang sama seperti ketika task diberikan dan dibahas di dalam perkuliahan. Maka dari itu model tes yang diberikan sudah menunjukkan keterkaitannya terhadap metode pembelajaran Problem Based Learning.

Pada tahap penilaian pada metode Problem Based Learning tidak ada ciri khusus untuk kriteria dalam pembuatan soal pada tes. Karena penilaian pada metode Problem Based Learning tidak hanya menggunakan tes saja. Penilaian juga dilakukan dengan menilai hasil pekerjaan peserta didik dan mendiskusikan secara bersama-sama. Jadi pemilihan model tes objektif digunakan karena model tes ini umum digunakan dan tidak terlalu sulit untuk diberikan kepada peserta didik guna mencapai tujuan dari proses pembelajaran.

\section{Pembahasan}

Berdasarkan hasil wawancara dan hasil dokumentasi diperoleh data bahwa, jenis penilaian yang digunakan adalah penilaian proses dan penilaian akhir. Pada proses pembelajaran penting untuk melakukan kegiatan asesmen atau penilaian. Karena tujuan dari penilaian ialah untuk mengetahui keberhasilan peserta didik dalam mencapai tujuan pembelajaran. Dalam hal ini dosen pengampu mata kuliah Bunpou $\mathrm{V}$ memperoleh penilaian proses dari aktivitas mahasiswa selama proses pembelajaran baik dari presentasi, hasil diskusi kelompok, maupun keaktifan secara individu. Sedangkan untuk penilaian akhir, dosen pengampu memberikan tes tulis untuk mengetahui hasil akhir dari proses perkuliahan yang berlangsung selama satu semester. Seperti yang dikatakan Purwanti (2001) bahwa teknik yang digunakan dalam kegiatan penilaian atau asesmen proses dan hasil belajar dibedakan menjadi dua yaitu teknik tes dan nontes. Diterapkannya penilaian proses dan akhir, sejalan dengan teori yang dikemukakan oleh Haryati (2009) bahwa penilaian (asesmen) merupakan istilah yang mencakup semua teknik yang digunakan untuk mengetahui hasil dari prestasi peserta didik selama proses pembelajaran dengan cara menilai unjuk kerja secara individu maupun berkelompok.

Popham (1995) menyatakan bahwa bentuk tes tertulis dibedakan menjadi dua golongan besar, yaitu: (1) soal-soal jawaban memilih (selected-response test), yang terdiri dari butir soal pilihan benar-salah (true-false items), butir soal pilihan ganda (multiple-choice items), dan butir soal menjodohkan (matching items); dan (2) soal-soal jawaban tersusun atau terstruktur (constructed-response tests), yang terdiri dari butir soal jawaban singkat 
(short-answer items), dan butir soal esai (esai items). Tes tulis yang diberikan berupa model tes pilihan ganda dan esai dengan rentangan skor yang berbeda. Secara teoritis dalam penerapan metode pembelajaran Problem Based Learning tidak memiliki kriteria khusus dalam penilaiannya, karena metode Problem Based Learning hanya mengutamakan pada kegiatan proses selama pembelajaran. Pemberian skor atau nilai ditentukan berdasarkan kebijakan dari dosen pengampu yaitu diambil dari kriteria umum dimana rentangan skor pada tes pilihan ganda lebih kecil (0-1) dibandingkan tes esai (0-2) yang menuntut jawaban sesuai dengan kemampuan mahasiswa dalam merangkai kalimat. Tes tulis ini digunakan pada aspek UTS (Ujian Tengah Semester) dan UAS (Ujian Akhir Semester).

Tes juga digunakan untuk mengukur hasil kemampuan belajar dari pebelajar untuk mencapai tujuan dari kegiatan proses pembelajaran. Dalam proses pembelajaran dapat dikatakan efektif apabila proses pembelajaran dapat membantu pembelajar untuk mempelajari sesuatu yang bermanfaat dan bisa mencapai hasil belajar yang diinginkan. Pada dasarnya sebelum penyusunan soal perlu dibuat persiapan. Persiapan pembelajaran tersebut harus disusun dengan jelas sesuai dengan kompetensi dasarnya. Adapun hal yang perlu dipersiapkan dosen pengampu sebelum pelaksanaan proses pembelajaran berlangsung yaitu berupa silabus dan rencana pelaksanaan pembelajaran.

Dalam penerapan metode Problem Based Learning dosen meminta peserta didik untuk membentuk kelompok diskusi. Setelah kelompok dibentuk nantinya mahasiswa harus mampu memecahkan masalah yang diberikan. Dengan penerapan model Problem Based Learning pada proses pembelajaran diharapkan mempengaruhi hasil akhir atau hasil belajar mahasiswa. Hal ini sejalan dengan pendapat yang dikemukakan oleh Akinoglu (2007) bahwa, "it was observed that the research group in which the Problem Based Learning model was used is more successful than the control groups to which traditional teaching methods were applied". Artinya, diperoleh hasil bahwa kelompok penelitian yang menggunakan model Problem Based Learning lebih sukses daripada kelompok kontrol yang menerapkan metode pembelajaran tradisional. Pada mata kuliah Bunpou $\mathrm{V}$ dosen pengampu sudah membagi mahasiswa menjadi beberapa kelompok yang nantinya mereka akan berdiskusi bersama untuk memecahkan masalah yang diberikan. Selama diskusi, mahasiswa dituntut untuk mampu menganalisis serta mengidentifikasi masalah yang ada dan mampu mempresentasikannya. Penerapan metode pembelajaran ini berpusat pada mahasiswa yang mengasah kemampuan berpikir, memecahkan masalah, serta mencari solusi dari masalah terebut. Sedangkan dosen hanya berperan sebagai fasilitator. Hal ini sudah sesuai dengan langkah-langkah Problem Based Learning oleh Riyanto (2009) yang dikatakan bahwa peserta didik harus aktif mencari informasi dan data yang berhubungan dengan masalah yang telah dirumuskan serta peserta didik juga mampu berdiskusi dengan kelompoknya untuk menyelesaikan masalah dan melaporkan hasil dari permasalahan yang diperoleh.

Dalam mata kuliah Bunpou V (Tata Bahasa V) dosen pengampu harus menyiapkan sebuah materi pembelajaran yang sesuai dengan silabus yang digunakan. Untuk pemberian materi yang diberikan yaitu berupa task yang berisikan pola-pola kalimat yang mengacu pada kompetensi dasar yang tertera pada silabus. Task atau tugas tersebut berupa materi ajar yang dibuat seperti soal beserta pilihan jawaban. Task yang diberikan pada setiap pertemuan berbeda-beda. Task ini yang dijadikan bahan untuk shoutesuto. Hal ini sesuai dengan prosedur atau langkah-langkah dalam pembelajaran Problem Based Learning yang dikatakan bahwa pengajar harus merumuskan dan memberikan masalah kepada peserta didik kemudian untuk dipecahkan dan dianalisis melalui diskusi kelompok.

Jumlah pola kalimat yang tercantum pada task setiap pertemuan berbeda-beda. Hal ini bergantung pada seberapa banyak pola kalimat yang diajarkan sesuai dengan acuan yang ada pada rencana perencanaan pembelajaran. Semakin banyak pola kalimat yang ada maka semakin banyak soal yang diberikan pada task tersebut. Model soal yang tercantum pada task berupa pernyataan dengan pilihan jawaban secara acak. Mahasiswa dituntut mampu menentukan partikel yang cocok dengan pernyataan tersebut. Pada saat perkuliahan pada tanggal 3 September 2015 task yang diberikan berupa 8 butir soal yang membahas materi terkait perbedaan partikel の (no) danこと(koto). Contohnya, petunjuk 
yang diberikan berupa kalimat perintah “( ) に「の」か「こと」を入れなさい。”“( ) ni [no] ka [koto] wo irenasai”. Sedangkan untuk pernyataannya berupa: 月刊誌という ( ) は 毎月一回発行される雑誌の ( )です。“gekkanshi to iu wa mai tsukiikka hakkou sareru zasshi no ( ) desu." Model yang digunakan dalam pernyataan tersebut berupa kalimat rumpang yang harus dilengkapi dengan partikel yang sudah ada agar menjadi satu kesatuan kalimat yang utuh dan bisa diterima.

Penggunaan model soal atau tes yang diberikan pada shoutesuto atau tes kecil hampir sama dengan model soal atau pernyataan yang dibahas pada task yang diberikan selama kegiatan proses pembelajaran Bunpou V. Shoutesuto atau tes kecil diadakan pada saat sebelum kegiatan proses pembelajaran Bunpou $\mathrm{V}$ dimulai. Waktu yang diberikan cukup singkat yaitu 6 sampai 7 menit pengerjaan. Karena waktu yang sangat singkat maka jumlah soal yang diberikan juga sedikit. Shoutesuto atau tes kecil ini dilaksanakan guna mengetahui sejauh mana mahasiswa memahami dan mengingat materi yang sudah pernah dibahas. Hasil nilai tes kecil akan tetap dimasukkan dalam nilai akhir. Untuk bobot penilaian dari tes kecil ini tidak tercantum pada kontrak kelas perkuliahan, namun nilai-nilai yang didapat oleh mahasiswa dari tes kecil ini akan di akumulasikan dan masuk pada aspek tugas.

Model tes yang diberikan pada saat UTS (Ujian Tengah Semester) dan UAS (Ujian Akhir Semester) hampir sama dengan model soal yang diberikan pada shoutesuto, yang membedakan hanya jumlah soal pada saat UAS lebih banyak dibandingkan UTS karena bobot penilaian pada aspek UAS lebih besar dibandingkan bobot penilaian pada aspek UTS.

Sedangkan untuk contoh model tes yang sudah diberikan pada saat UTS dan UAS misalnya, dengan kalimat perintah berupa “つぎの分に適当な言葉を( ) の中選んでください。”“tsugi no bun ni tekitouna kotoba wo naka kara erande kudasai.” Soal diambil dari beberapa contoh yang ada pada dokumen soal-soal yang diberikan pada saat ujian dan pernyataannya sebagai berikut.

あのレストランは、味がいい

\{ばかりでなく、ばかりに、ばかり\}、サーアスもいい。”“ano resutoran wa, aji ga ii \{bakaridenaku, bakarini, bakari\}, saabisu mo ii” .

Dapat dilihat bahwa model soal atau tes yang diberikan berupa pernyataan yang masih rumpang dan sudah disediakan pilihan jawabannya. Model tes ini termasuk model tes dengan jawaban memilih atau pilihan ganda. Sejalan dengan yang diungkapkan oleh Sudaryono (2012) bahwa tes pilihan ganda merupakan tes yang terdiri atas suatu keterangan tentang suatu pengertian yang belum lengkap atau masih rumpang. Dan untuk melengkapinya harus memilih salah satu dari beberapa kemungkinan jawaban yang telah disediakan. Jenis tes ini dipilih karena luasnya bahan pembelajaran yang didapat dicakup dalam tes dan mudahnyamenilai jawaban yang diberikan. Berdasarkan hasil dokumentasi, model tes yang diberikan mulai dari task, shoutesuto, UTS, maupun UAS secara keseluruhan memiliki model yang sama yaitu berupa pernyataan yang rumpang namun sudah tertera pilihan jawabannya.

Pada soal UTS yang diberikan, diambil dari soal-soal yang sudah pernah dibahas dan diberikan pada saat shoutesuto atau tes kecil sebelum perkuliahan. Sedangkan, soal Ujian Akhir Semester (UAS) diambil dari penggabungan soal selama shoutesuto dan UTS. Jumlah soal yang diberikan pada saat UTS lebih sedikit dibandingkan soal yang diberikan pada saat UAS karena untuk bobot penilaian pada aspek UTS hanya $30 \%$ dan untuk bobot penilaian pada saat aspek UAS sebesar $40 \%$ sesuai dengan kontrak kelas perkuliahan. Pada soal UTS dan UAS terdapat soal yang hanya memilih satu kalimat rumpang serta terdapat soal yang harus mengisi dua kalimat rumpang (khusus untuk percakapan) namun skor yang diberikan rentangannya sama yaitu 0-1. Pemberian tes-tes yang telah diberikan kepada mahasiswa dimaksudkan agar hasil akhir yang diperoleh lebih baik serta dapat dijadikan evaluasi bagi pendidik mengenai kemampuan mahasiswa tersebut. Hal ini sesuai dengan pendapat yang dikemukakan oleh Nicol (2007) bahwa, "Frequent assessment tasks, especially diagnostic tests, can help teachers generate cumulative information about studens' levels of understanding and skill, so that they can adapt their teaching accordingly". Artinya, tugas yang sering diberikan, khususnya tes diagnostik dapat membantu guru 
menghasilkan informasi kumulatif tentang tingkat pemahaman dan keterampilan siswa, sehingga pendidik dapat menyesuaikan pembelajaran yang diberikan. Hal ini menunjukkan bahwa penilaian atau asesmen sangat penting dilakukan oleh pendidik agar nantinya kemampuan siswa semakin meningkat seiring dengan meningkatnya kualitas tes yang diberikan.

Berdasarkan penilaian yang diterapkan pada metode Problem Based Learning, penilaian proses efektif diterapkan dalam mata kuliah Bunpou V (Tata Bahasa V) karena dengan adanya penilaian proses mahasiswa lebih aktif dalam mengajukan pendapat serta berpartisipasi dalam proses pembelajaran. Dengan adanya penilaian proses, maka mempengaruhi penilaian akhir yaitu nilai UTS dan UAS mahasiswa yang ditunjukkan dengan nilai yang diperoleh sebagian besar sudah di atas rata-rata.

Sebagai suatu penelitian yang telah dilakukan di lingkungan pendidikan, maka kesimpulan yang dapat ditarik tentu mempunyai implikasi dalam bidang pendidikan dan penelitian selanjutnya, terkait dengan hal itu maka implikasinya sebagai berikut:

Hasil penelitian ini memfokuskan pada tahap asesmen atau penilaian yaitu dengan cara mengumpulkan instrumen yang digunakan pada saat proses pembelajaran berlangsung serta pada akhir pembelajaran. Instrumen yang digunakan pada penilaian akhir adalah tes. Sedangkan pada penilaian proses dinilai seberapa aktif mahasiswa selama proses pembelajaran. Hal ini bisa memberikan kontribusi kepada tenaga pendidik atau calon tenaga pendidik dalam melakukan asesmen atau penilaian pada metode Problem Based Learning dalam mata kuliah Bunpou V (Tata Bahasa V).

Tenaga pendidik juga harus mampu mengkreasikan secara lebih kreatif proses pembelajaran dengan menerapkan suatu metode pembelajaran, agar peserta didik merasa senang dan mudah memahami materi yang diberikan. Tujuan melaksanakan kegiatan asesmen atau penilaian adalah untuk mengetahui kemampuan peserta didik selama proses pembelajaran. Pada tahap asesmen, tenaga pendidik harus mampu membuat instrumen yang sesuai dengan konteks pembelajaran guna untuk mengetahui tujuan dari pembelajaran dan kemampuan peserta didik. Pada proses penilaian juga penting adanya rancangan yang dibuat dan direncanakan secara detail, sehingga dalam pelaksanaannya dapat meminimalisir kendala yang memungkinkan terjadi.

\section{Simpulan dan Saran}

Berdasarkan atas permasalahan yang dirumuskan dan hasil yang diperoleh dari penelitian, maka dapat disimpulkan hal-hal sebagai berikut:

1) Penilaian proses diperoleh dari aktivitas mahasiswa selama perkuliahan berlangsung yakni berupa penilaian terhadap hasil presentasi, hasil diskusi, dan penilaian untuk keaktifan secara individu. Berdasarkan hasil studi dokumentasi diketahui bahwa sebagian besar mahasiswa telah aktif dalam pembelajaran dengan metode Problem Based Learning.

2) Penilaian produk dilaksanakan dengan memberikan tes tulis yang diberikan pada saat UTS dan UAS untuk mengetahui kemampuan mahasiswa serta memperoleh nilai akhir pada proses pembelajaran . berdasarkan hasil studi dokumentasi diperoleh hasil bahwa ratarata nilai shoutesuto,UTS, dan UAS mahasiswa berada diatas rata-rata.

Berdasarkan hasil penelitian dari simpulan, maka peneliti dapat menyarankan hal-hal sebagai berikut.

1) Metode pembelajaran Problem Based Learning diharapkan untuk diterapkan lagi pada kegiatan proses pembelajaran lainnya. Karena metode ini sudah cukup baik diterapkan dengan tujuan agar pebelajar lebih aktif sesuai dengan kurikulum pembelajaran yang menuntut untuk hal itu. Untuk tenaga pengajar yang nantinya akan melaksanakan tahap asesmen dalam mengajar mampu mengkreasikan proses pembelajaran agar peserta didik merasa nyaman dan kegiatan proses pembelajaran terasa lebih menyenangkan.

2) Tenaga pendidik diharapkan mampu melakukan penilaian yang baik dan benar sesuai dengan tujuan pembelajaran .

3) Pada saat pembuatan tes dalam kegiatan asesmen atau penilaian agar mampu membuat soal dengan model tes yang sesuai dengan kebutuhan peserta didik dan mampu 
mengukur sejauh mana kemampuan dan pemahaman materi yang diberikan ketika proses pembelajaran.

\section{Daftar Pustaka}

Akinoglu, Orhan dan Ruhan Ozkardes Tandogan. 2007. "The Effect of Problem Based Learning in Science Education on Students' Academic Achievement, Attitude and Concept Learning". Eurasian Journal of Mathematics, Science \& Technology Education. Vol.3, No.1. Tersedia pada https://eric.ed.gov/. Diakses pada 22 Desember 2017.

Arikunto, Suharsimi. 2006. Prosedur Penelitian, Suatu Pendekatan Praktik. Jakarta: Rineka Cipta.

Haryati. 2009. Model \& Teknik Penilaian pada Tingkat Satuan Pendidikan, Jakarta:Gaung Persada. hal 15.

Khadafianto, Rahayu, Suryadi. 2016. "Rancangan Perbaikan Penilaian Tutorial Berdasarkan Sudut Pandang Tutor dan Mahasiswa serta Literatur". Jurnal Pendidikan Kedokteran Indonesia. Vol. 5, No.2.

Mardani dan Adnyani. 2015. "Implementasi Metode Problem Based Learning pada Mata Kuliah Bunpou IV (Tata Bahasa IV) di Jurusan Pendidikan Bahasa Jepang, Universitas Pendidikan Ganesha". Laporan Penelitian Jurusan (tidak diterbitkan). Jurusan Pendidikan Bahasa Jepang, FBS UNDIKSHA.

Moleong, Lexy J. 2011. Metode Penelitian Kualitatif. Bandung: Remaja Rosdakarya.

Nicol, David J. \& Debra Macfarlane-Dick. 2007. "Formative Assement and Self -regulated Learning: A Model and Seven Principles of Good Feedback Practice". Studies in Higher Education. Vol.31. No.2. Tersedia pada srhe.tandfonline.com/. Diakses pada 22 Desember 2017.

Popham, W.J. 1995. Classroom Assesment, What Teachers Need it Know. Oxford: Pergamon Press.

Purwanti, Endang. 2001. Evaluasi pembelajaran, Modul Akta mengajar. UMM Press.

Riyanto, Yatim. 2009. Paradigma Baru Pembelajaran Sebagai Referensi bagi Pendidikan Dalam implementasi Pembelajaran yang Efektif. Jakarta: Kencana.

Sudaryono. 2012. Dasar-dasar Evaluasi Pembelajaran. Yogyakarta. Graha Ilmu.

Sugiyono. 2009. Metode Penelitian Pendekatan Kuantitatif, Kualitatif, dan R\&D. Bandung: Alfabeta.

Sukmadinata. 2006. Metode Penelitian Kualitatif. Bandung: Graha Aksara.

Suryabrata, Sumadi. 1987. Metode Penelitian. Jakarta: Rajawali. h. 93. 